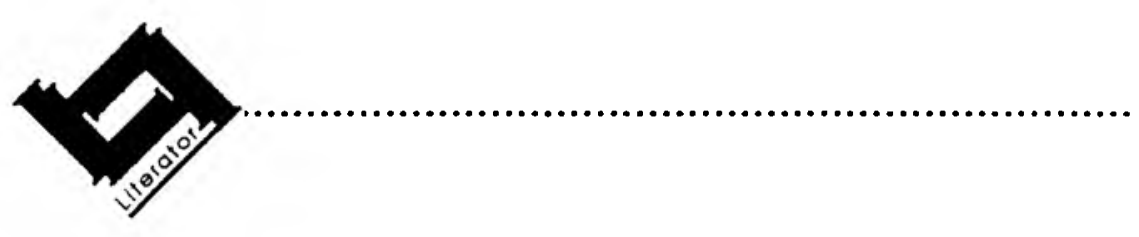

\title{
In memoriam: Agnes Barbara Bosch
}

Op 15 Oktober is die Afrikaanse taalkundige wêreld tot stilstand geruk deur die doodstyding van prof. Barbara Bosch, een van die mees geliefde en bekwame akademici in ons vakgebied van hierdie dekade. Dié wat die voorreg gehad het om nader aan haar invloedsfeer te leef as bloot op kollegiale vlak, sal weet dat sy ook een van die mees gebalanseerde ménse was wat die Oos-Kaap, en Grahamstad in die besonder, geken het. Binne die bestek van die 47 jaar wat haar gegun is, het sy met oorgawe 'n sukses gemaak van student-wees, eggenote- en mawees, en 'n staatmaker geword in die gemeenskap wat sy haar tuiste gemaak het.

By die roudiens wat in die volgepakte universiteitskapel by Rhodes gehou is, was dit duidelik uit die huldigingsredes wat gelewer is dat haar invloed in die gemeenskap oor taal- en kultuurgrense heen gestrek en talle mense se lewens geraak het. In die konteks van haar gesin en vriendekring was sy 'n immer viendelike gasvrou, baaskok en tuisteskepper, in dié van die omringende gemeenskap 'n uiters waardevolle deelnemer aan skool-, kerk- en kultuurliggame. Dit was asof sy eers sorg gedra het het dat haar gemeenskaps- en gesinsverpligtings nagekom is, en dat sy haar terselfdertyd as dosent en waardevolle kollega in beroepsverband gevestig het, voordat sy gedurende die laaste 7 jaar van haar lewe navorsing gedoen het teen 'n tempo wat min akademici haar sou kon nadoen. Nie minder nie as 73 publikasies het in hierdie kort tyd onder haar hand die lig gesien. Selfs in die laaste paar maande van haar stryd teen kanker het sy nog twee artikels geskryf wat binnekort in 'n vaktydskrif sal verskyn.

Haar navorsing het onderwerpe ingesluit soos sintaksis, taalhoudings, naamgewing, vrouetaal en die tekslinguistiek, en het getuig van 'n fyn waarneming van haar leefwêreld. Lesers van Literator sal haar bydraes oor 'n verskeidenheid van hierdie onderwerpe onthou. Daarbenewens het sy ook as keurder opgetree vir talle taalkundige artikels in hierdie tydskrif.

Sy was op nasionale vlak bekend deur haar betrokkenheid by vakkundige verenigings soos die Linguistevereniging, waarin sy tot haar dood redakteur was van die vaktydskrif ( $S A$ Tydskrif vir Taalkunde), asook by die Naamkundevereniging, die Vereniging vir Toegepaste Taalstudies, ensomeer. Haar naam is drie keer agtereenvolgens opgeneem in die register van die 500 leidende vroue in Suid- 
Afrika. Ook internasionaal is daar erkenning verleen aan haar bydrae, onder andere deurdat haar naam verskyn het in die Marquis Who's Who in the World, die Dictionary of International Biography, en The World Who's Who of Women. Ironies is sy selfs deur die Intemational Biographical Centre in Cambridge geselekteer as 'n International Man of the Year vir 1996/1997.

Ons sal Barbara onthou as 'n mens-mens, wat intens in haar medemens belang gestel het, wie se hart en deur oopgestaan het vir dié wat haar pad gekruis het. In 'n laaste gesprek met haar op 22 September 1998 het sy nog met groot belangstelling by my navraag gedoen oor die wel en wee van kollegas en vriende van elders, al was sy deeglik bewus van haar eie kritieke toestand.

As tipiese akademikus het sy 'n gesonde nuuskierigheid gehad oor elke verskynsel wat oor haar pad gekom het, ook oor die dood wat, soos sy mettertyd besef het, onwrikbaar voor haar kom staan het en haar uitgedaag het om hom te ontleed en te ontmitologiseer. Ook dié uitdaging het sy aanvaar en deur die insigte van ander navorsers soos Elizabeth Kibler-Ross haarself as diep gelowige voorberei op die bevrydende knip van die aardse naelstring. Die groot insig wat selfs die mees intelligente onder ons bly ontglip, naamlik dat 'n mens die wysheid oor die hiernamaals slegs kan bekom deur soos 'n kind te wees, oop en onbevange, was van die laaste bevindinge wat sy gemaak het.

Die Afrikaanse taalkundewêreld is 'n uiters begaafde kollega armer, maar iemand wat deur haar lewe en werk 'n ryk nalatenskap vir ons gegee het en daarvoor eer ons haar nagedagtenis.

\section{Prof. E.F. Kotzé}

Dept. Afrikaans en Nederlands Universiteit van Port Elizabeth 